\title{
The Good Wife's Guide
}


To view this image, please see the printed book. 


\section{The}
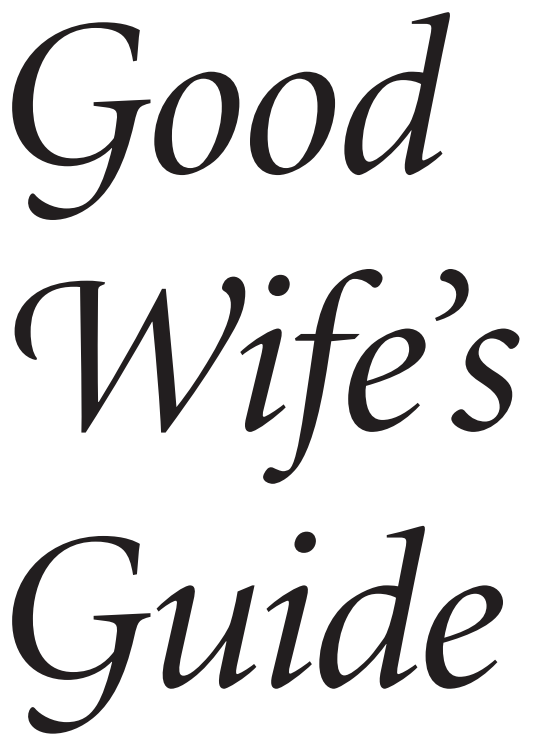

LE MÉNAGIER DE PARIS

A MEDIEVAL HOUSEHOLD BOOK

Translated, with Critical Introduction, by

GINA L. GRECO \& CHRISTINE M. ROSE

CORNELL UNIVERSITY PRESS

ITHACA AND LONDON 


\section{Copyright () 2009 by Cornell University}

All rights reserved. Except for brief quotations in a review, this book, or parts thereof, must not be reproduced in any form without permission in writing from the publisher. For information, address Cornell University Press, Sage House, 512 East State Street, Ithaca, New York 14850.

First published 2009 by Cornell University Press

First printing, Cornell Paperbacks, 2009

Printed in the United States of America

The Library of Congress Cataloging-in-Publication Data may be found on the last page of this book.

Cornell University Press strives to use environmentally responsible suppliers and materials to the fullest extent possible in the publishing of its books. Such materials include vegetablebased, low-VOC inks and acid-free papers that are recycled, totally chlorine-free, or partly composed of nonwood fibers. For further information, visit our website at www.cornellpress. cornell.edu.

Cloth printing $\quad \begin{array}{llllllllll}10 & 9 & 8 & 7 & 6 & 5 & 4 & 3 & 2 & 1\end{array}$

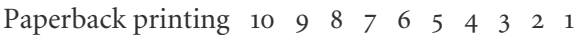

FRONTISPIECE:

Le Ménagier MS A, Paris, Bibliothèque nationale de France, fonds français 12477, fol. 1. Small image before the beginning of the text ("Chiere seur...") of a man and woman conversing. 
TO GAETANO AND JOHN 
